\title{
A Minimum Guaranteed Jobs Proposal
}

\author{
David Colander \\ Middlebury College, Middlebury, Vermont 05753, USA.
}

Eastern Economic Journal (2016) 42, 666-669. doi:10.1057/eej.2016.7; published online 27 June 2016

Given the growth in inequality in the past decades, there is an understandable push by progressives for the United States to increase the minimum wage. This push complements the long-time push by progressives for the government to provide everyone with a guaranteed minimum income. The goal, to provide a safety net for the poor, is laudable. Unfortunately, the programs are misplaced and almost doomed to failure. The reason: both programs work against the market, not with it, and as long as the United States remains a market economy, any workable safety net will have to work with the market.

There is a better way to provide a safety net in a market economy. Instead of trying to provide a minimum wage or a minimum income to the poor, government should structure its safety net programs to provide everyone in our society with a way in which they can translate their time into a minimally acceptable income. Market economies do that by providing jobs. Unfortunately, the US economy provides too few minimally acceptable jobs, which is what necessitates the need for a safety net. The best way to provide a safety net for people able to work in a market economy is for the government to act as the employer of last resort. If the market fails to provide individuals with a minimum job, government steps in and provides it.

A minimum job program achieves the combined goals of a minimum wage and a minimum income program while avoiding serious problems with each. The reason why is because the minimum jobs program works with the market while both the minimum wage and minimum income programs work against the market.

A minimum income program works against the market because it creates incentives not to work. If you know you are going to get a minimum income independent of whether or not you work, why work. That's why all attempts to establish a guaranteed minimum income have failed. A guaranteed minimum jobs program works differently; the way you get your minimum income is by working. Similarly, a minimum wage program works against the market because it creates incentives to fire workers; if an employer has to pay workers a higher wage, that employer will hire fewer workers, increasing unemployment.

A guaranteed minimum job program eliminates unemployment and leaves private firms free to offer whatever wage they choose. What's different from our current system is that, with a guaranteed minimum job, low-wage workers have a viable alternative, which puts them in a better bargaining position to push for better working conditions and higher wages. The compatibility of the minimum jobs program with the market can be seen by recognizing that it operates only when the market isn't working. If the market provides minimally acceptable jobs for everyone, then the minimum jobs program becomes superfluous. 
If all people in society have access to a guaranteed job, society doesn't need a minimum wage program - if someone wants to work for a lower wage than the guaranteed job pays (because the private market job provides better training, because it is more fun, or because of any other reason) they are free to do so. But they will choose an alternative job only if they see the private market job, in all its dimensions, as preferable to the guaranteed minimum job. Thus, whereas a minimum wage program discourages firms from offering training, a minimum job program encourages firms to provide jobs that offer job training and good working conditions. The guaranteed jobs program provides a type of flexible minimum wage depending on the nature and desirability of the job. Highly undesirable jobs will have to pay significantly above the minimum guaranteed job wage if they are to find workers. More desirable jobs that include training and other benefits can pay below the minimum guaranteed job wage.

Similarly if everyone in society has access to a guaranteed job, society doesn't need a minimum income program for those able to work; people have a way to earn a minimum income and the market is encouraged to increase the desirability of the jobs it provides.

\section{DESIGN CHARACTERISTICS OF A GUARANTEED JOBS PROGRAM}

A guaranteed jobs program can take many different forms depending on the nature of the minimum job being guaranteed. The primary purpose of the guaranteed jobs is to provide individuals with a method of translating their time into income. The goal is not to provide individuals with a deeply satisfying job. The reality is that most low-wage market jobs are not deeply satisfying. The equilibrium wage rate for deeply satisfying jobs is likely zero or more likely negative.

To give you an idea of how a guaranteed minimum jobs program might be structured, and what it would cost, let me outline some characteristics of what I see as a compromise proposal designed to take into account conservative's concern about costs of the program and progressive's concern about providing an acceptable minimum safety net.

The design characteristics of a basic minimum jobs program might be the following: ${ }^{1}$

- The government in its role as employer of last resort will provide a guaranteed minimum job for eligible citizens

- The pay for the job will be US\$10.00 an hour, and workers will be allowed to work for up to 40 hours per week. This will provide everyone in the labor force with the ability to earn a minimum income of $\$ 400$ per week, or $\$ 20,800$ per year

- The guaranteed job will consist of a variety of mental and physical tasks that can be easily monitored either online or within existing institutions. The mental tasks might be activities such as keyboarding practice, doing arithmetic exercises on an internet training program, doing exercises in word processing, doing spread sheets, reading reports and summarizing them, or completing online courses. The physical tasks might include doing specific exercises, digging holes and filling them, moving weights, and other similar type activities. The goal of these activities is not to produce usable output for society, but to provide work activities by which people can translate their time into income. To the degree possible, these working experiences will provide training in skills and an introduction to customs and behavior useful in the real-world market jobs

- The guaranteed minimum job will require the worker to go to work at standard working hours - variations of an 8 hour day — and meet the normal job requirements that lowwage private and government employers impose on their employees - dress codes, behavior codes, such as showing up on time, demonstrating the appropriate attitude, and being responsible. Individuals who do not meet these standards can be fired 
- Whenever possible the guaranteed job would be designed to help people learn new skills that would make them more productive and provide certification of any increase in productivity. For example, for those who have not graduated from high school, the job activities might prepare them to get their GED (General Educational Development) degree. A number of skill certifications might be created, which guaranteed job workers will be encouraged to earn on the job to provide them with credentials that will help them find better-paying jobs in the normal job market

- Government will contract with for-profit, non-profit, and governmental firms and organizations to monitor and mentor the workers in the set of specified activities. These organizations will receive a stipend for monitoring the jobs, and possibly be allowed to have the person work for them at no cost for up to one-fifth of the hours they work. Likely contractees would include existing small manufacturing and retail firms, nongovernmental organizations, and governmental organizations, such as schools, that have space and the ability to undertake this monitoring. The guaranteed workers would be a bit like interns for them. Depending on monitoring feasibility, there might also be virtual jobs, in which the guaranteed job and the monitoring are done over the internet

- Ideally all citizens willing and able to work would be eligible for the guaranteed program, but practically, eligibility will likely have to be limited. For example, initially it will likely be necessary to restrict eligibility to non-full-time students; otherwise the program would likely be overwhelmed by students wanting summer work. To be feasible, the program will also likely have to be limited to US citizens; if open to immigrants, and undocumented residents, it would likely be too costly

\section{THE COST OF A GUARANTEED JOBS PROGRAM}

The costs of the program are dependent on the design characteristics: the more inclusive and expansive these design characteristics are, the greater the cost. To give you a rough ballpark figure for the costs, let's consider what a guaranteed jobs program with the above design characteristics might cost.

At $\$ 10$ an hour the cost per worker for 40 hours a week is about $\$ 21,000$ per worker per year. Add to that $\$ 5,000$ per job for administration and monitoring, and one arrives at a cost of $\$ 26,000$ per job provided.

How many people will choose these jobs depends on the state of the economy. In 2016, there are about 8 million people unemployed. Only a portion of those currently classified as unemployed would choose to participate in this guaranteed government jobs program. Even many of the long-term unemployed would likely not choose to participate, preferring instead to be supported by their family, friends, or savings. My rough estimate is that with the job characteristics listed above, 30 percent of the measured unemployed, or 2.4 million, might choose to participate.

Assuming that full-time students, Social Security recipients, and non-citizens are not eligible for the guaranteed jobs, there might be another 1.6 million workers interested in the program. These would include discouraged workers who had dropped out of the labor force because of lack of any hope of finding a job, and workers at jobs that they would find less desirable than the guaranteed job.

As those low-wage workers leave their current jobs, their current employers would be forced to raise their pay or otherwise improve working conditions if they are to stay in business. Particularly undesirable jobs will likely have to pay significantly more than $\$ 10$ an hour to retain workers, and the price they charge for their products would similarly have to rise. (The other jobs that low-wage workers did would either be moved abroad 
or automated; all market jobs must meet the minimum guaranteed job standard.) So the guaranteed jobs program not only helps those in the program, it also helps lowwage workers outside the program.

As these improvements in private market jobs occur, fewer than the 1.6 additional million workers will choose the guaranteed job. Perhaps closer to 1 million additional workers would choose to participate, with the 600,000 staying at their private jobs at the higher wage and improved conditions.

Taking all the adjustments into account, in today's economy, a rough estimate of the number of people who would choose to participate in the guaranteed job program might be a total of 3.4 million.

At $\$ 26,000$ per job for pay and administration, and another $\$ 10$ billion for overall administration of the program, the total cost would be a bit under $\$ 90$ billion. That certainly is not cheap. But it is doable. For a plan that provides a safety net and eliminates the need for the minimum wage and a minimum income program, it is a bargain.

\section{Note}

1. None of these design characteristics are set in stone; I provide them merely to provide some sense of the type of decisions that would have to be made in an actual program. 